\title{
KEDUDUKAN HUKUM ADMINISTRASI NEGARA DALAM ILMU HUKUM
}

\author{
I Nyoman Artayasa \\ Fakultas Ilmu Sosial Dan Ilmu Politik, Universitas Mahendradatta - Denpasar \\ e-mail : arta_yasa66@yahoo.com
}

\begin{abstract}
Abstrak - Hukum Administarsi Negara adalah Hukum mengenai Pemerintah/Eksekutif didalam kedudukannya, tugas-tuganya, fungsi dan wewenangnya sebagai Administrator Negara. Hukum Administrasi Negara merupakan salah satu cabang/bagian dari ilmu hukum yang khusus. Hukum Administrasi Negara merupakan ilmu hukum yang tidak statis,akan tetapi berkembang sesuai dengan perkembangan kebutuhan dalam masyarakat. Di dalam ilmu hukum publik, mula-mula Hukum Administrasi Negara merupakan bagian dari Hukum Tata Negara, kuliah-kuliah Hukum Administrasi Negara ditempelkan dalam Hukum Tata Negara. Fungsi Hukum Administrasi Negara yaitu : Menjamin Kepastian Hukum,. Menjamin Keadilan Hukum,. Hukum Administrasi Berfungsi Sebagai Pedoman dan Ukuran.
\end{abstract}

Kata kunci: hukum administrasi negara,hukum tata negara

\begin{abstract}
State Administrative Law is the Law regarding the Government / Executive in its position, duties, functions and authority as a State Administrator. State Administrative Law is one branch / part of specialized legal science. State Administrative Law is a legal science that is not static, but develops according to the development of needs in society. In public law, at first State Administrative Law is part of the State Law, lectures on State Administrative Law are embedded in the State Law. The function of State Administrative Law, namely: Ensuring Legal Certainty. Guaranteeing Legal Justice. Administrative Law Works As A Guide and Size.
\end{abstract}

Keywords: state administrative law

\section{PENDAHULUAN}

Sejarah Hukum Administrasi Negara atau Hukum Tata Usaha Negara (HTUN) atau Hukum Tata Pemerintahan ( HTP ) di Negeri Belanda disatukan dalam Hukum Tata Negara yang disebut Staats en Administratiefrecht. Pada tahun 1946 di Universitas Amsterdam baru diadakan pemisahan Hukum Administrasi Negara mata kuliah Administrasi Negara dari mata kuliah $\mathrm{Hu}-$ kum Tata Negara, dan Mr. Vegting sebagai guru besar yang memberikan mata kuliah Hukum Administrasi Negara. Tahun 1948 Universitas Leiden mengikuti jejak Universitas Amsterdam memisahkan Hukum Administrasi Negara dari Hukum Tata Negara yang diberikan oleh Kranenburg. Di Indonesia sebelum perang dunia kedua pada Rechtshogeschool di Jakarta diberikan dalam satu mata kuliah dalam Staats en administratiefrecht yang diberikan oleh Mr. Logemann sampai tahun 1941. Baru pada tahun 1946 Universitas Indonesia di Jakarta Hukum Administrasi Negara dan Hukum Tata Negara diberikan secara tersendiri. Hukum Tata Negara diberikan oleh Prof. Resink, sedangkan Hukum Administrasi Negara diberikan oleh Mr. Prins. Berdasarkan uraian-uraian di atas jelaslah bahwa Ilmu Hukum Administrasi Negara adalah ilmu yang sangat luas dan terus berkembang mengikuti tuntutan $\mathrm{Ne}$ gara/masyarakat, sehingga lapangan yang akan digalinyapun sangat luas dan beranekan ragam dan campur tangan pemerintah dalam kehidupan masyarakat.

Hukum administrasi berisi peraturan-peraturan yang menyangkut administrasi. Administrasi sendiri berarti bestuur (pemerintah). Dengan demikian, hukum administrasi (administratief recht) dapat juga disebut dengan hukum tata pemerintahan (bestuursrecht). Pemerintah (bestuur) juga dipandang sebagai fungsi pemerintahan (bestuursfunctie) yang merupakan penguasa yang tidak termasuk 
pembentukan UU dan peradilan.

Hukum Administrasi Negara merupakan salah satu cabang atau bagian dari hukum yang khusus. Dalam studi Ilmu Administrasi, mata kuliah Hukum Administrasi Negara merupakan bahasan khusus tentang salah satu aspek dari administrasi, yakni bahasan mengenai aspek hukum dari administrasi Negara. Sedangkan dikalangan PBB dan kesarjanaan internasional, Hukum Administrasi Negara diklasifikasi baik dalam golongan ilmu-ilmu hukum maupun dalam ilmu-ilmu administrasi.

\section{Permasalahan}

Tujuan dari penulisan jurnal ini adalah untuk menambah serta memberikan wawasan mengenai Hukum Administrasi Negara, supaya mengetahui kedudukan serta fungsi-fungsi Hukum Administrasi Negara.

a. Kedudukan Hukum Administrasi Negara dalam ilmu hukum

b. Hubungan Hukum Administrasi Negara dengan cabang hukum yang lain

c. Fungsi Hukum Administrasi Negara

\section{Manfaat Penelitian}

1. Secara Akademis dapat digunakan sebagai bahan masukan/referensi bagi Pemerintah meningkatkan pemahaman terhadap Hukum Administrasi negara.

2. Secara praktik dapat memberikan masukan dalam upaya meningkatkan kualitas penegakan hukum.

\section{IV.TINJAUAN PUSTAKA}

Pada dasarnya definisi Hukum Administrasi Negara sangat sulit untuk dapat memberikan suatu definisi yang dapat diterima oleh semua pihak, mengingat Ilmu Hukum Administrasi Negara sangat luas dan terus berkembang mengikuti arah penyelenggaraan suatu Negara. Namun sebagai pegangan dapat diberikan beberapa definisi sebagai berikut :

1. Oppen Hein mengatakan Hukum Administrasi Negara adalah sebagai suatu gabungan ketentuan-ketentuan yang mengikat badan-badan yang tinggi maupun rendah apabila badan-badan itu menggunakan wewenagnya yang telah berikan kepadanya oleh Hukum Tata Negara.
2. J.H.P. Beltefroid mengatakan Hukum Administrasi Negara adalah keseluruHukum Administrasi Negara aturan-aturan tentang cara bagaimana alat-alat pemerintaHukum Administrasi Negara dan badan-badan kenegaraan dan majelis-majelis pengadilan tata usaha hendak memenuhi tugasnya.

3. Logemann mengatakan Hukum Administrasi Negara adalah seperangkat dari norma-norma yang menguji hubungan Hukum Istimewa yang diadakan untuk memungkinkan para pejabat administrasi Negara melakukan tugas mereka yang khusus.

4. E. Utrecht mengatakan Hukum Administarsi Negara adalah menguji hubungan hukum istimewa yang diadakan agar memungkinkan para pejabat pemerintahan Negara melakukan tugas mereka secara khusus.

Jadi ada tiga ciri-ciri Hukum Administarsi Negara :

1. Menguji hubungan hukum istimewa 2. Adanya para pejabat pemerintahan 3. Melaksanakan tugas-tugas istimewa.

Prajudi Atmosudirdjo mengatakan Hukum Administarsi Negara adalah hukum mengenai operasi dan pengendalian dari kekuasaan-kekuasaan administrasi atau pengawasan terhadap penguasa-penguasa administrasi.

Dari pengertian-pengertian di atas jelaslah bahwa bidang hukum administrasi Negara sangatlah luas, banyak segi dan macam ragamnya. Pemerintah adalah pengurus dari pada Negara, pengurus Negara adalah keseluruhan dari jabatan-jabatan didalam suatu Negara yang mempunyai tugas dan wewenang politik Negara dan pemerintahan. Apa yang dijalankan oleh pemerintah adalah tugas Negara dan merupakan tanggung jawab dari pada alat-alat pemerintahan. Dengan demikian dapat disimpulkan bahwa $\mathrm{Hu}-$ kum Administrasi Negara adalah $\mathrm{Hu}-$ kum mengenai Pemerintah/Eksekutif didalam kedudukannya, tugas-tugasnya, fungsi dan wewenangnya sebagai Administrator Negara. 
V. Ruang Lingkup Hukum Administarsi Negara

Menurut Walther Burckharlt (Swiss), bidang-bidang pokok Hukum Administrasi Negara adalah:

1. Hukum Kepolisian

Kepolisian dalam arti sebagai alat administrasi Negara yang sifat preventif misalnya pencegahan dalam bidang kesehatan, penyakit flu burung, malaria,pengawasan dalam pembangunan, kebakaran, lalu lintas, lalulintas perdagangan ( Ekspor-Impor).

2. Hukum Kelembagaan, yaitu administrasi wajib mengatur hubungan hokum sesuai dengan tugas penyelenggara kesejahtreaan rakyat misalnya dalam bidang pendidikan, rumah sakit, tentang lalu lintas ( laut, udara dan darat), Telkom, BUMN, Pos, pemeliharaan fakir miskin, dan sebagainya.

3. Hukum Keuangan, aturan-aturan tentang keuangan Negara, misalnya pajak, bea cukai, peredaran uang, pembiayaan Negara dan sebagainya.

Prajudi Atmosudirdjo mengatakan bahwa ruang lingkup Hukum Administarsi Negara adalah :

a. Hukum tentang dasar-dasar dan prinsip-prinsip umum daripada Administrasi Negara.

b. Hukum tentang organisasi dari Administrasi Negara.

c. Hukum tentang aktifitas-aktifitas dari Administrasi Negara yang bersifat yuridis.

d. Hukum tentang sarana-sarana dari Administrasi Negara terutama mengenai kepegawaian Negara dan keuangan Negara.

e. Hukum Administrasi Pemerintahan Daerah dan wilayah yang dibagi menjadi :

1. Hukum Administrasi Kepegawaian

2. Hukum Administrasi Keuangan

3. HukumAdministrasi Materiil

4. Hukum Administrasi Perusahaan Negara

f. Hukum tentang Peradilan Administrasi Negara

Kusumadi Pudjosewojo, membagi bidang-bidang pokok yang merupakan lapangan HukumTata Usaha Negara atau Hukum Adminsitrasi Negara, yang diam- bil dari Undang-undang Dasar Sementara adalah sebagai berikut :

a. Hukum Tata Pemerintahan.

b. Hukum Tata Keuangan

c. Hukum Hubungan Luar Negeri

d. Hukum Pertahanan dan Keamanan Umum

\section{PEMBAHASAN}

\section{Kedudukan Hukum Administrasi Ne- gara dalam Ilmu Hukum}

Hukum Administrasi Negara merupakan salah satu cabang/bagian dari ilmu hukum yang khusus. Hukum Admianstrasi Negara merupakan ilmu hukum yang tidak statis,akan tetapi berkembang sesuai dengan perkembangan kebutuhan dalam masyarakat.Di dalam ilmu hukum publik, mula-mula Hukum Administrasi Negara merupakan bagian dari Hukum Tata Negara, kuliah-kuliah Hukum Admianstrasi Negara ditempelkan dalam Hukum Tata Negara.

Negara hukum modern yang mengutamakan kesejahteraan rakyat pada akhir abad 19 dan permulaan abad 20 (antara tahun (1946-1948) diadakan pemisahan antara Hukum Administrasi Negara dengan Hukum Tata Negara. Hukum Administrasi Negara berkembang dengan pesat, kemudian Hukum Administrasi Negara diakui merupakan bagian tersendiri dari hukum publik dan sebagian ada pada hukum privat.

Philipus M.Hadjon dkk mengemukakan bahwa hukum administrasi materiil terletak diantara hukum privat dan hukum pidana (publik). Hukum pidana berisi norma-norma yang begitu penting (esensial) bagi kehidupan masyarakat sehingga penegakan norma-norma tersebut tidak diserahkan pada pihak partikelir tetapi harus dilakukan oleh penguasa. Hukum privat berisi norma-norma yang penegakannya dapat diserahkan pada pihak partikelir. Diantara bidang hukum itu terletak hukum administrasi. Oleh karenanya Hukum Administrasi Negara dapat dikatakan sebagai hukum antara. Hubungan Antara Hukum Administrasi Negara dan Hukum Tata Negara.

Ada dua golongan pendapat mengenai hubungan antara Hukum Administrasi Ne- 
gara dengan Hukum Tata Negara:

a. Golongan pertama,menyatakan ada perbedaan yuridis prinsipil antara $\mathrm{Hu}-$ kum Administrasi Negara dengan $\mathrm{Hu}-$ kum Tata Negara.

b. Golongan kedua menyatakan tidak ada perbedaan yuridis prinsipil antara $\mathrm{Hu}-$ kum Administrasi Negara dengan $\mathrm{Hu}-$ kum Tata Negara.

Para ahli yang berpendapat bahwa ada perbedaan yuridis prinsipil antara Hukum Administrasi Negara dan Hukum Tata Negara adalah Oppenheim, Van Vollenhoven dan Logeman. Sedangkan pendapat kedua yang menyatakan tidak ada perbedaan yuridis prinsipil antara Hukum Administrasi Negara dan Hukum Tata Negara diikuti oleh Kranenburg, Prins, dan Prajudi Atmosudirdjo.

Oppenheim, menyatakan bahwa yang dipersoalkan Hukum Tata Negara adalah negara dalam keadaan berhenti sedangkan Hukum Administrasi Negara adalah peraturan-peraturan hukum mengenai negara dalam keadaan bergerak. Hukum Tata Negara merupakan kumpulan peraturan-peraturan hukum yang membentuk alat-alat perlengkapan negara dan memberikan kepadanya wewenang yang membagi-bagikan tugas pekerjaan dari pemerintah modern antara bebeeapa alat perlengkapan negara di tingkat tinggi dan tingkat rendah. Sedangkan Hukum Admianstrasi Negara adalah sekumpulan peraturan-peraturan hukum yang mengikat alat-alat perlengkapan yang tinggi maupun yang rendah dalam menggunakan wewenangnya yang telah diberikan/ditetapkan dalam Hukum Tata Negara.

Van Vollenhoven menyatakan bahwa yang termasuk di dalam Hukum Admianstrasi Negara, adalah semua peraturan hukum nasional sesudah dikurang Hukum Tata Negara materiil, hukum perdata materiil dan hukum pidana materiil. Hubungan antara Hukum Tata Negara dengan Hukum Admianstrasi Negara, yaitu bahwa badan-badan kenegaraan memperoleh wewenang dari Hukum Tata Negara dan badan-badan kenegaraan itu menggunakan wewenangnya harus berdasarkan atau sesuai dengan Hukum Administrasi Negara.

Logeman mengemukakan bahwa $\mathrm{Hu}-$ kum Tata Negara merupakan suatu pe- lajaran tentang kompetensi, sedangkan Hukum Administrasi Negara merupakan suatu pelajaran tentang perhubungan-perhubungan hukum istimewa. Menurutnya Hukum Tata Negara mempelajari :

a. Jabatan-jabatan apa yang ada dalam susunan suatu negara;

b. Siapa yang mengadakan jabatan tersebut;

c. Dengan cara bagaimana jabatan-jabatan itu ditempati oleh pejabat;

d. Fungsi/lapangan kerja dari jabatan-jabatan itu;

e. Kekuasaan hukum dari jabatan-jabatan itu;

f. Hubungan antara masing-masing jabatan;

g. Dalam batas-batas manakah organ-organ kenegaraan dapat melakukan tugasnya.

Sedangkan yang dipelajari dalam $\mathrm{Hu}-$ kum Administrasi Negara yaitu sifat, bentuk dan akibat hukum yang timbul karena perbuatan hukum istimewa yang dilakukan oleh para pejabat dalam menjalankan tugasnya. Kranenburg, Prins dan Prajudi Atmosudirdjo menyatakan bahwa antara Hukum Administrasi Negara dengan Hukum Tata Negara tidak ada perbedaan yuridis prinsipiil, perbedaan yang ada Hukum Administrasi Negaraya pada titik berat/fokus pembahasan. Hukum Tata Negara fokusnya adalah hukum rangka dasar dari negara sebagai keseluruHukum Administrasi Negara, sedangkan Hukum Administrasi Negara fokusnya merupakan bagian khusus dari Hukum Tata Negara.

Kranenburg menyatakan bahwa kalau di dalam praktek ada perbedaan, Hukum Administrasi Negaraya karena untuk mencapai kemanfaatan dalam penyelidikan. Menurutnya yang digolongkan dalam $\mathrm{Hu}-$ kum Tata Negara adalah peraturan-peraturan yang mengatur struktur umum dari suatu pemerintaHukum Administrasi Negara negara, misalnya UUD dan UU organic (UU yang mengatur daerah-daerah otonom), Hukum Administrasi Negara berisi UU dan peraturan-peraturan khusus misalnya : hukum kepegawaian.

Prins mengemukakan bahwa Hukum Tata Negara mempelajari hal-hal yang fundamental yang merupakan dasar-dasar dari negara dan langsung menyangkut tiap-tiap warga negara, sedangkan Hukum 
Administrasi Negara menitikberatkan pada hal-hal yang teknis saja, yang $\mathrm{Hu}-$ kum Administrasi Negaraya penting bagi para spesialis. Disendirikannya Hukum Administrasi Negara dari Hukum Tata Negara tidak karena adanya perbedaan tugas antara Hukum Tata Negara dan Hukum Administrasi Negara, akan tetapi karena sudah sedemikian berkembangnya Hukum Administrasi Negara, sehingga memerlukan perhatian tersendiri bukan sebagai tambaHukum Administrasi Negara/sampiran Hukum Tata Negara saja.

Prajudi Atmosudirdjo menyatakan bahwa perbedaan Hukum Tata Negara dan Hukum Administrasi Negara Hukum Administrasi Negaraya terletak pada titik berat dalam pembahasan. Di dalam mempelajari Hukum Tata Negara fokus perhatian ada pada konstitusi negara sebagai keseluruhan, sedangkan di dalam Hukum Administrasi Negara fokus atau titik berat perhatian kita secara khas kepada administrasi negara. Hubungan antara Hukum Administrasi Negara dengan Hukum Tata Negara mirip dengan hubungan antara $\mathrm{Hu}-$ kum Dagang dengan Hukum Perdata, di mana Hukum Dagang merupakan spesialisasi dari Hukum Perikatan di dalam $\mathrm{Hu}-$ kum Perdata. Hukum Administrasi Negara merupakan spesialisasi belaka pada salah satu bagian dari Hukum Tata Negara, sehingga asas-asas dan kaidah-kaidah dari Hukum Tata Negara yang bersangkutan dengan administrasi negara berlaku pula bagi Hukum Administrasi Negara.

\section{Hubungan Hukum Administrasi Nega- ra dengan Cabang Ilmu Hukum Lain- nya}

a. Hukum Administrasi Negara dengan Hukum Tata Negara

Baron de Gerando adalah seorang ilmuwan Perancis yang pertama kali mempekenalkan ilmu hukum administrasi $\mathrm{Ne}$ gara sebagai ilmu hukum yang tumbuh langsung berdasarkan keputusan-keputusan alat perlengkapan Negara berdasarkan praktik kenegaraan sehari-hari. Maksudnya, keputusan raja dalam menyelesaikan sengketa antara pejabat dengan rakyat merupakan kaidah Hukum Administrasi Negara.Mr. W.F. Prins menyatakan bahwa Hukum Administrasi Negara merupakan bagian Hukum Administrasi Negaragsel (embel-embel atau tambahan) dari hukum tata negara. Sementara Mr. Dr. Romeyn menyatakan bahwa Hukum Tata Negara menyinggung dasar-dasar dari pada negara dan Hukum Administrasi Negara adalah mengenai pelaksanaan tekniknya. Pendapat Romeyn ini dapat diartikan bahwa Hukum Administrasi Negara adalah sejenis hukum yang melaksanakan apa yang telah ditentukan oleh Hukum Tata Negara, dan sejalan dengan teori Dwi Praja dari Donner, maka Hukum Tata Negara itu menetapkan tugas (taakstelling) sedangkan Hukum Administrasi Negara itu melaksanakan apa yang telah ditentukan oleh Hukum Tata Negara (taakverwezenlijking).

Menurut Van Vollenhoven, secara teoretis Hukum Tata Negara adalah keseluruhan peraturan hukum yang membentuk alat perlengkapan Negara dan menentukan kewenangan alat-alat perlengkapan Negara tersebut, sedangkan Hukum Administrasi Negara adalah keseluruhan ketentuan yang mengikat alat-alat perlengkapan Negara, baik tinggi maupun rendah ketika alat-alat itu akan menggunakan kewenangan ketatanegaraan. Pada pihak yang satu terdapatlah hukum tata negara sebagai suatu kelompok peraturan hukum yang mengadakan badan-badan kenegaraan, yang memberi wewenang kepada badan-badan itu, yang membagi pekerjaan pemerintah serta memberi bagian-bagian itu kepada masing-masing badan tersebut yang tinggi maupun yang rendah. Hukum Tata Negara menurut Oppenheim yaitu memperhatikan negara dalam keadaan tidak bergerak (staat in rust). Pada pihak lain terdapat Hukum Administrasi negara sebagai suatu kelompok ketentuan-ketentuan yang mengikat badan-badan yang tinggi maupun rendah bila badan-badan itu menggunakan wewenangnya yang telah diberi kepadanya oleh hukum tata negara itu. Hukum Administrasi negara itu menurut Oppenheim memperhatikan negara dalam keadaan bergerak (staat in beweging).

Tidak ada pemisahan tegas antara hukum tata Negara dan hukum administrasi. Terhadap hukum tata Negara, hukum administrasi merupakan perpanjangan dari hukum tata Negara. Hukum administrasi melengkapi hukum tata Negara, disamping sebagai hukum instrumental (instrumenteel recht) juga menetapkan perlindungan 
hukum terhadap keputusan - keputusan penguasa.

Yang menjadi sulit adalah ketika membicarakan distribusi kewenangan dari pejabat administrasi negara, karena ketika kita menganalisis yang akan bertemu dengan teori steufen bau des recht nya Kelsen mau tidak mau kita akan melihat tata urutan perUUan mulai dari Norma dasar (grundnorm) yg merupakan norma tertinggi sampai kepada norma yang paling bawah dengan melakukan analisis sinkronisasi vertikal. Ketika membicarakan hal itu semuanya akan menjadi abu-abu antar Hukum Administrasi Negara dengan Hukum Tata Negara. Akan tetapi mudahnya kita lihat saja kalau ujung tombaknya Hukum Tata Negara adalah Konstitusi, sementara Ujung tombaknya Hukum Administrasi Negara adalah kewenangan.

Ketika kita berbicara kewenangan kita akan membicarakan kedua konsep $\mathrm{Hu}-$ kum Administrasi Negara yaitu Hukum Administrasi Negara Heteronom ( bersumber pada UUD, Tap MPR, dan UU, yakni hukum yang mengatur seluk beluk organisasi dan fungsi administrasi negara) dan Hukum Administrasi Negara Otonom (adalah hukum operasional yang dicipta oleh Pemerintah dan Administrasi Negara sendiri). Ketika melihat kedua definisi tersebut maka dapat disimpulkan kalau Hukum Administrasi Negara Otonom sebagai pengopersionalisasian kewenangan bersumber pada Hukum Administrasi Negara Heteronom.

Hukum Tata Negara bisa dikatakan sebagai dasar dari Hukum Administrasi Negara namun pada penyelenggaraan pemerintaHukum Administrasi Negara $\mathrm{Hu}-$ kum Administrasi Negara akan lebih luas daripada Hukum Tata Negara karena $\mathrm{Hu}-$ kum Administrasi Negara yang mempunyai kewenangan dalam pelaksanaan pemerintaHukum Administrasi Negara akan mempunyai kebijakan-kebijakan lain, beschiking dan freis ermesen yang akan digunakan untuk menjalankan pemerintaHukum Administrasi Negara sesuai dengan amanat perundang-undangan dan sesuai dengan asas-asas pemerintaHukum Administrasi Negara. Terkadang tindakan pejabat administrasi negara secara sepihak diperlukan ketika keadaan mendesak dan perundang-undangan belum ada yang mengatur akan hal itu. b. Hukum Administrasi Negara dengan Hukum Pidana

Romeyn berpendapat bahwa hukum Pidana dapat dipandang sebagai baHukum Administrasi Negara pembantu atau "hulprecht" bagi hukum tata pemerintaHukum Administrasi Negara, karena penetapan sanksi pidana merupakan satu sarana untuk menegakkan hukum tata pemerintaHukum Administrasi Negara, dan sebaliknya peraturan-peraturan hukum di dalam perundang-undangan administratif dapat dimasukkan dalam lingkungan hukum Pidana. Sedangkan E. Utrecht mengatakan bahwa Hukum Pidana memberi sanksi istimewa baik atas pelanggaran kaidah hukum privat, maupun atas pelanggaran kaidah hukum publik yang telah ada.

Hukum administrasi materiil terletak diantara hukum privat dan hukum pidana. Hukum administrasi dapat dikatakan sebagai "hukum antara" (Poly-Juridisch Zakboekje h. B3/4). Sebagai contoh Izin Bangunan. Dalam memberikan izin penguasa memperhatikan segi-segi keamanan dari bangunan yang direncanakan. Dalam hal demikian, pemerintah menentukan syarat-syarat keamanan. Disamping itu bagi yang tidak mematuhi ketentuan-ketentuan tentang izin bangunan dapat ditegakkan sanksi pidana. W.F. Prins mengemukakan bahwa "hampir setiap peraturan berdasarkan hukum administrasi diakhiri in cauda venenum dengan sejumlah ketentuan pidana (in cauda venenum secara harfiah berarti ada racun di ekor/ buntut).

\section{c. Hukum Administrasi Negara dengan} Hukum Perdata

Menurut Paul Scholten sebagaimana dikutip oleh Victor Situmorang bahwa Hukum Administrasi Negara itu merupakan hukum khusus hukum tentang organisasi negara dan hukum perdata sebagai hukum umum. Pandangan ini mempunyai dua asas yaitu pertama, negara dan badan hukum publik lainnya dapat menggunakan peraturan-peraturan dari hukum perdata, seperti peraturan-peraturan dari hukum perjanjian. Kedua, adalah asas Lex Specialis derogaat Lex generalis, artinya bahwa hukum khusus mengesampingkan hukum umum, yaitu bahwa apabila suatu 
peristiwa hukum diatur baik oleh Hukum Administrasi Negara maupun oleh hukum Perdata, maka peristiwa itu diselesaikan berdasarkan Hukum Administrasi negara sebagai hukum khusus, tidak diselesaikan berdasarkan hukum perdata sebagai hukum umum.

Oleh karena itu terjadinya hubungan antara Hukum Administrasi Negara dengan Hukum Perdata apabila:

1. Saat atau waktu terjadinya adopsi atau pengangkatan kaidah hukum perdata menjadi kaidah hukum Administrasi Negara

2. Badan Administrasi negara melakukan perbuatan-perbuatan yang dikuasasi oleh hukum perdata

3. Suatu kasus dikuasai oleh hukum perdata dan hukum administrasi negara maka kasus itu diselesaikan berdasarkan ketentuan-ketentuan Hukum Administrasi Negara.

d. Hukum Administrasi Negara dengan Ilmu Administrasi Negara

Sebagaimana istilah administrasi, administrasi negara juga mempunyai berbagai macam pengertian dan makna. Dimock dan Dimock, menyatakan bahwa sebagai suatu studi, administrasi negara membahas setiap aspek kegiatan pemerintah yang dimaksudkan untuk melaksanakan hukum dan memberikan pengaruh pada kebijakan publik (public policy); sebagai suatu proses, administrasi negara adalah seluruh langkah-langkah yang diambil dalam penyelesaian pekerjaan; dan sebagai suatu bidang kemampuan, administrasi negara mengorganisasikan dan mengarahkan semua aktivitas yang dikerjakan orang-orang dalam lembaga-lembaga publik.

Kegiatan administrasi negra tidak dapat dipisahkan dari kegiatan politik pemerintah, dengan kata lain kegiatan-kegiatan administrasi negara bukanlah Hukum Administrasi Negaraya melaksanakan keputusan-keputusan politik pemerintah saja, melainkan juga mempersiapkan segala sesuatu guna penentuan kebijaksanaan pemerintah, dan juga menentukan keputusan-keputusan politik.

\section{e. Fungsi Hukum Administrasi Negara}

1. Menjamin Kepastian Hukum

Menjamin kepastian hukum yang menyangkut masalah bentuk dari hukum.

2. Menjamin Keadilan Hukum

Keadilan hukum yang dimaksud adalah keadilan yang telah ditentukan oleh undang-undang dan peraturan tertulis.

3. Hukum Administrasi Berfungsi Sebagai Pedoman dan Ukuran.

Pedoman artinya sebagai petunjuk arah dari perilaku manusia yaitu perilaku yang baik dan benar, ukuran maksudnya untuk menilai apakah pelaksanaan tersebut telah dilaksanakan dengan benar atau tidak

\section{KESIMPULAN}

Hukum administrasi negara merupakan hukum yang berisi peraturan-peraturan yang menyangkut administrasi dalam suatu pemerintah. Hukum Administrasi Negara umum, yakni hukum yang mengatur tindakan pemerintah dengan pemerintahan atau hubungan antar organ pemerintahan dalam suatu negara.

Hukum administrasi negara memiliki: kedudukan, hubungan dengan cabang hukum yang lain, Landasan, fungsi yang berjalan sesuai kegunaan dan memiliki sebuah proses masing-masing dalam kelangsungan hukum yang ada di negara Indonesia khususnya dalam pemerintahan.

\section{DAFTAR PUSTAKA}

Muchsan, SH. 1982. Pengantar Hukum Administrasi Negara, Yogyakarta: Liberty.

Muchsan, SH. 1981. Peradilan Administrasi Negara. Yogyakarta: Liberty.

Phillipus M. Hadjon dkk. 1993. Pengantar Hukum Administrasi Indonesia. Yogyakarta: Gadjah Mada University Press.

Prajudi Atmosudirdjo, Prof. Dr. Mr., 1983, Hukum Administrasi Negara, Ghalia Indonesia, Jakarta;

SF Marbun dkk. 2001. Dimensi-Dimensi Pemikiran Hukum Administrasi Negara. Yogyakarta: UII Press.

Utrecht, E. 1986. Pengantar Hukum Administrasi Negara. Surabaya: Pustaka Tinta Mas. 